\title{
Interleukin-8/CXCL8 is a growth factor for human lung cancer cells
}

\author{
YM Zhu*,', SJ Webster', D Flower' and PJ Woll' \\ 'Department of Clinical Oncology, Institute for Cancer Studies, University of Sheffield Medical School, Beech Hill Road, Sheffield SIO 2RX, UK
}

Interleukin-8/CXCL8 (IL-8) is a chemokine and angiogenic factor. Recently, IL-8 was identified as an autocrine growth factor in several human cancers. Here, we investigated the expression and function of IL-8 in lung cancer cells. The expressions of IL-8 and its receptors, CXCRI and CXCR2, were examined in a panel of non-small cell lung cancer (NSCLC) and small cell lung cancer (SCLC) cell lines. Using reverse transcription-polymerase chain reaction (RT-PCR) and enzyme-linked immunosorbent assay, we found that all NSCLC cell lines tested produced modest or high levels of IL-8 (up to $51 \mathrm{ng} \mathrm{ml}^{-1} 10^{6} \mathrm{cell}^{-1}$ ). Expression of CXCRI and CXCR2 was found by RT-PCR and flow cytometry in two out of three cell lines. In contrast, SCLC cell lines produced very low or undetectable levels of IL-8, but expressed CXCRI and CXCR2. We next investigated whether IL-8 could act as an autocrine growth factor in two NSCLC cell lines (H460 and MOR/P) expressing both IL-8 and its receptors. We found that cell proliferation was attenuated by anti-IL-8 neutralising antibody to $7 \mathrm{I}$ and $76 \%$ in $\mathrm{H} 460$ and MOR/P, respectively $(P<0.05)$. Exogenous IL-8 significantly stimulated cell proliferation in four SCLC cell lines tested in a dose-dependent fashion. Cell proliferation was increased by between I 8\% $(P<0.05)$ and 37\% $(P<0.05)$. Stimulation of cell proliferation by IL-8 was also demonstrated by analysis of proliferating cell nuclear antigen expression and cell cycle in $\mathrm{H} 69$ cells. Furthermore, we investigated which receptor(s) mediated the mitogenic function of IL-8 in lung cancer cells. We found that cell proliferation was significantly reduced by anti-CXCRI antibody but not by anti-CXCR2 antibody. In conclusion, IL-8 can act as an autocrine and/or paracrine growth factor for lung cancer cells, and the mitogenic function of IL-8 in lung cancer is mediated mainly by CXCRI receptor.

British Journal of Cancer (2004) 9I, 1970- 1976. doi: I 0. I 038/sj.bjc.6602227 www.bjcancer.com

Published online 16 November 2004

(c) 2004 Cancer Research UK

Keywords: interleukin-8/CXCL8; CXCRI; CXCR2; lung cancer

Lung cancer is the leading cause of cancer-related death in industrialised countries. The majority of patients with lung cancer have incurable advanced disease with very poor therapeutic options, so new treatment approaches such as targeted therapy are urgently needed. The malignant phenotype of lung cancer may be partially attributable to abnormalities in growth factors and their receptors acting via both autocrine and paracrine pathways. An understanding of the abnormal expression of such growth factors and their receptors is crucial to find new therapeutic targets. Lung cancer can be classified into small cell lung cancer (SCLC), which has a neuroendocrine phenotype, and non-small cell lung cancer (NSCLC), which includes adenocarcinoma, squamous cell carcinoma and large cell carcinoma. Both SCLC and NSCLC have been shown to produce a variety of growth factors (Woll, 1996).

Interleukin-8/CXCL8 (IL-8) is a member of the CXC chemokine family, which was originally classified as a neutrophil chemoattractant with inflammatory activity (Baggiolini et al, 1989). Two IL-8 receptors, CXCR1 and CXCR2, have been identified. They

*Correspondence: Dr YM Zhu; E-mail: y.m.zhu@sheffield.ac.uk Received 2 June 2004; revised 23 September 2004; accepted 23 September 2004; published online 16 November 2004 share $77 \%$ amino-acid identity and belong to the superfamily of seven transmembrane domain, $G$ protein-coupled receptors, whose signalling is mediated by heterotrimeric $G$ proteins, resulting in the exchange of GDP for GTP on the $\alpha$ subunit of the G protein (Wess, 1997). CXCR1 and CXCR2 have been found on many normal cells such as neutrophils, basophils, lymphocytes, monocytes, keratinocytes and endothelial cells.

Interleukin- 8 is a potent angiogenic factor in several cancers including NSCLC (Smith et al, 1994) and is associated with metastasis (Singh et al, 1994; Ueda et al, 1994; Luca et al, 1997). Elevated IL-8 is correlated with angiogenesis, tumour progression and poor survival in NSCLC (Yuan et al, 2000; Masuya et al, 2001; Orditura et al, 2002; Chen et al, 2003). CXCL8 has been shown to be mitogenic for cancers such as melanoma (Schadendorf et al, 1993), colon cancer (Brew et al, 2000; Li et al, 2001), pancreatic cancer (Miyamoto et al, 1998), malignant mesothelioma (Galffy et al, 1999) and Kaposi's sarcoma (Masood et al, 2001). However, the role of IL-8 in lung cancer has been controversial. It was shown that the inhibition of lung cancer growth by targeting IL-8 in a mouse model was solely due to the inhibition of the angiogenic effect of IL-8 (Arenberg et al, 1996). Interleukin-8 was also shown to inhibit directly lung cancer cell proliferation in vitro (Wang et al, 1996). CXCR1 and CXCR2 were found on a variety of tumour cells, but have not been reported in lung cancer. In this study, we investigated the expression of IL- 8 and its receptors, CXCR1 and 
CXCR2, in a panel of NSCLC and SCLC cell lines and characterised the mitogenic role of IL-8 in lung cancer growth.

\section{MATERIALS AND METHODS}

\section{Lung cancer cell lines and cell culture}

The SCLC cell lines used were CORL-24, GLC-19, H69, H345, H711 and Lu-165. The NSCLC cell lines used were A549, H460 and MOR/ P. All cell lines were cultured in RPMI 1640 (BioWhittaker, Verviers, Belgium) and 10\% FBS (QB perbio, Tattenhall, Cheshire, UK) in humidified $5 \% \mathrm{CO}_{2}, 95 \%$ air at $37^{\circ} \mathrm{C}$. Conditioned medium was obtained by collecting medium from MOR/P $\left(5 \times 10^{7}\right.$ cells $)$ or $\mathrm{H} 460\left(5 \times 10^{6}\right.$ cells) cells cultured in $5 \mathrm{ml}$ of $10 \%$ FBS in RPMI 1640 for $48 \mathrm{~h}$.

\section{Reverse transcription-polymerase chain reaction}

The expression of mRNA for IL-8 and its receptors was determined by reverse transcription-polymerase chain reaction (RT-PCR). Total RNA was isolated by using the RNeasy mini kit (Qiagen, West Sussex, UK) following the manufacturer's protocol. A $0.5 \mu \mathrm{g}$ portion of total RNA was reverse-transcribed for subsequent PCR amplification for each pair of primers in a volume of $10 \mu \mathrm{l}$, including $10 \mathrm{U}$ of enhanced AMV reverse transcriptase (Sigma, Poole, Dorset, UK), $20 \mathrm{U}$ of RNase inhibitor (Sigma), $0.5 \mu \mathrm{g}$ of oligo $(\mathrm{dT})_{15}$ primer, $0.5 \mathrm{nmol}$ of each $\mathrm{dNTP}$ and $1 \times$ first-strand buffer ( $50 \mathrm{~mm}$ Tris- $\mathrm{HCl}, \mathrm{pH} 8.3,40 \mathrm{~mm} \mathrm{KCl}, 8 \mathrm{~mm} \mathrm{MgCl}_{2}, 1 \mathrm{~mm}$ dithiothreitol) provided by Sigma. The reaction was incubated at $45^{\circ} \mathrm{C}$ for $50 \mathrm{~min}$. A $10 \mu \mathrm{l}$ portion of the RT products was then brought to a volume of $50 \mu \mathrm{l}$ containing $0.2 \mathrm{nmol}$ of each dNTP, $1 \mathrm{U}$ of Taq polymerase (Sigma), $0.1 \mu \mathrm{g}$ of both the upstream and downstream PCR primers and $1 \times$ PCR buffer $(10 \mathrm{~mm}$ Tris- $\mathrm{HCl}$, $\mathrm{pH} 8.3,50 \mathrm{~mm} \mathrm{KCl}, 1.1 \mathrm{~mm} \mathrm{MgCl}_{2}, 0.01 \%$ gelatin) provided by Sigma. The primers for IL-8 are as follows: sense, $5^{\prime}$-ATG ACT TCC AAG CTG GCC GTG GCT-3'; antisense, 5'-TCT CAG CCC TCT TCA AAA ACT TCT-3'. The primers for CXCR1 are as follows: sense, $5^{\prime}$-CCT TCT TCC TTT TCC GCC AG-3'; antisense, $5^{\prime}$-AAG TGT AGG AGG TAA CAC GAT G - $3^{\prime}$; The primers for CXCR2 are as follows: sense, 5'-ATT CTG GGC ATC CTT CAC AG-3'; antisense, $5^{\prime}$-TGC ACT TAG GCA GGA GGT CT- $3^{\prime}$. The primers for GAPDH are as follows: sense, $5^{\prime}$-CCA CCC ATG GCA AAT TCC ATG GCA-3'; antisense, 5'-TCT AGA CGG CAG GTC AGG TCC ACC- $3^{\prime}$. Amplification was carried out in a Biometra thermal cycler after an initial denaturation at $94^{\circ} \mathrm{C}$ for $3 \mathrm{~min}$. This was followed by 35 cycles of PCR using the following temperature and time profile: denaturation at $94^{\circ} \mathrm{C}$ for $40 \mathrm{~s}$, primer annealing at $58^{\circ} \mathrm{C}$ for $40 \mathrm{~s}$, primer extension at $72^{\circ} \mathrm{C}$ for $1 \mathrm{~min}$ and a final extension of $72^{\circ} \mathrm{C}$ for $6 \mathrm{~min}$. The PCR products were visualised by electrophoresis on a $2 \%$ agarose gel in $0.5 \times$ TBE buffer $(44.5 \mathrm{mM}$ Tris borate, $1 \mathrm{~mm}$ EDTA, pH 8.3) after staining with $0.5 \mu \mathrm{g} \mathrm{ml}^{-1}$ ethidium bromide.

\section{Enzyme-linked immunosorbent assay}

The expression of IL-8 protein was determined by enzyme-linked immunosorbent assay (ELISA). For collecting samples from culture media, serum-free RPMI medium was used. The media were harvested at the indicated times and stored at $-20^{\circ} \mathrm{C}$ before analysis. The concentrations of IL-8 in the culture media were determined by ELISA ( $R \& D$ systems, Abingdon, UK) according to the manufacturer's instructions. Briefly, $100 \mu \mathrm{l}$ samples containing standard amounts of recombinant IL-8 (rIL-8) or study samples were added in triplicate to individual wells and incubated at room temperature for $1 \mathrm{~h}$. After five washes, $100 \mu \mathrm{l}$ of biotinylated IL-8 antibody diluted in dilution buffer $(0.1 \%$ bovine serum albumin, $0.05 \%$ Tween 20 in Tris-buffered saline $(20 \mathrm{~mm}$ Trizma-base, $150 \mathrm{~mm} \mathrm{NaCl}$ )) was added for $1 \mathrm{~h}$. After another five washes, $100 \mu \mathrm{l}$ of streptavidin-horseradish peroxidase (HRP) conjugate that had been diluted to $1 / 200$ in dilution buffer was added for $30 \mathrm{~min}$. After a final wash, $100 \mu \mathrm{l}$ of the substrate buffer containing the HRP substrate tetramethylbenzidine dihydrochloride and hydrogen peroxide in $0.05 \mathrm{M}$ phosphate-citrate buffer ( $\mathrm{pH} 5.0$ ) was added for $30 \mathrm{~min}$ in the dark and colour developed in proportion to the amount of IL-8 present. The reaction was stopped by adding $100 \mu \mathrm{l}$ of stop solution ( $1.8 \mathrm{M}$ sulphuric acid), and the degree of colour that had been generated was determined by measuring the optical density (OD) at $450 \mathrm{~nm}$ in a Dynatech MR5000 microplate reader.

\section{Flow cytometry analysis of cell surface expression of CXCR1 and CXCR2}

The cells were washed twice with phosphate-buffered saline (PBS) and then suspended in $100 \mu \mathrm{l}$ of FACS buffer ( $2 \%$ bovine serum albumin, $2 \%$ normal rabbit serum in PBS), and then $2 \mu \mathrm{g}$ of mouse anti-human monoclonal anti-CXCR1 or anti-CXCR2 antibody or IgG control antibody (R\&D systems) was added and incubated for $40 \mathrm{~min}$ on ice. After washing twice with PBS, the cells were suspended in $100 \mu \mathrm{l}$ of FACS buffer plus $1: 20$ diluted FITCconjugated rabbit anti-mouse IgG (DAKO, Denmark) and incubated for $30 \mathrm{~min}$ on ice. The cells were washed twice with PBS and fixed in $100 \mu \mathrm{l}$ of FACS buffer containing $1 \%$ paraformaldehyde. The cells were analysed on a FACSort flow cytometer (Becton Dickinson, San Jose, CA, USA).

\section{Staining of proliferating cell nuclear antigen and DNA}

The cells were suspended in $100 \mu \mathrm{l}$ of PBS and then $500 \mu \mathrm{l}$ of lysing buffer $\left(0.5 \%\right.$ Triton X-100, $0.2 \mu \mathrm{g} \mathrm{ml}^{-1}$ EDTA, $1 \%$ BSA in PBS) was added for $15 \mathrm{~min}$ on ice. The cells were fixed with $3 \mathrm{ml}$ of $100 \%$ icecold methanol for $10 \mathrm{~min}$, washed once with PBS, and then $2 \mu \mathrm{g}$ of mouse anti-human monoclonal anti-proliferating cell nuclear antigen (PCNA, clone PC 10, Sigma) or control mouse $\operatorname{IgG}_{2 \mathrm{a}}$ antibody (R\&D systems) diluted in lysing buffer was added and incubated for $30 \mathrm{~min}$ at room temperature. After washing twice with PBS, the cells were suspended in $100 \mu \mathrm{l}$ of lysing buffer plus 1:20 diluted FITC-conjugated rabbit anti-mouse IgG (DAKO, Denmark) and incubated for $30 \mathrm{~min}$. The cells were washed once with PBS and $200 \mu \mathrm{l}$ of DNA-staining solution $\left(10 \mu \mathrm{g} \mathrm{ml}^{-1}\right.$ propidium iodide, $0.2 \mathrm{mg} \mathrm{ml}^{-1}$ RNase, $0.1 \%$ Triton X-100 in PBS) was added at room temperature for at least $15 \mathrm{~min}$. The cells were analysed on a FACSort flow cytometer.

\section{MTT assay}

Cell proliferation was measured by 3-(4,5-dimethylthiazol-2-yl)2,5-diphenyltetrazolium bromide (MTT) assay (Sigma, Dorset, England). A total of $5 \times 10^{3}$ cells were seeded into 96-well flatbottomed plates in triplicate in $100 \mu \mathrm{l}$ RPMI containing 10\% FCS. After overnight culture, cells were treated with various concentrations of rIL-8, monoclonal anti-IL-8, monoclonal anti-CXCR1, monoclonal anti-CXCR2 or control antibody - mouse IgG (R\&D systems) - and conditioned medium of MOR/P and H460 for $48 \mathrm{~h}$. A $10 \mu \mathrm{l}$ portion of MTT $\left(5 \mathrm{mg} \mathrm{m}^{-1}\right)$ was added to each well $4 \mathrm{~h}$ before the end of experiments. Then, MTT solvent $(100 \mu \mathrm{l}$ of $0.1 \mathrm{~N}$ $\mathrm{HCl}$ in anhydrous isopropanol) was added and absorbance of the converted dye was measured at a wavelength of $570 \mathrm{~nm}$. The background was also measured at $690 \mathrm{~nm}$.

\section{Statistical analysis}

All results are expressed as mean \pm s.d. The unpaired Student's $t$ test was used to evaluate the significance of differences between groups, accepting $P<0.05$ as the level of significance. 


\section{RESULTS}

\section{Constitutive production of IL-8 in lung cancer cell lines}

Expression of IL-8 mRNA was detected by RT-PCR, and was found expressed in all NSCLC cell lines: A549, H460 and MOR/P. Although IL-8 mRNA was weakly expressed in the SCLC cell lines H69, H345 and H711, it was not expressed in Lu165, CORL24 and GLC-19 cell lines (Figure 1A). To assess protein production, IL-8 was measured by ELISA in the supernatants of unstimulated cells cultured in serum-free medium. No detectable IL-8 was found in all cell lines after $6 \mathrm{~h}$ of culture. In all three NSCLC cell lines, IL-8 was detected after $24 \mathrm{~h}, \mathrm{H} 460$ cells produced $6153 \mathrm{pg} \mathrm{ml}^{-1} 10^{6} \mathrm{cells}^{-1}$, MOR/P $584 \mathrm{pg} \mathrm{ml}^{-1} 10^{6} \mathrm{cells}^{-1}$ and A549 $357 \mathrm{pg} \mathrm{ml}^{-1} 10^{6} \mathrm{cells}^{-1}$. After $48 \mathrm{~h}$, IL-8 levels were increased to $51282 \mathrm{pg} \mathrm{ml}^{-1} 10^{6} \mathrm{cells}^{-1}$ in $\mathrm{H} 460,7299 \mathrm{pg} \mathrm{ml}^{-1} 10^{6} \mathrm{cells}^{-1}$ in MOR/P and $2053 \mathrm{pg} \mathrm{ml}^{-1} 10^{6} \mathrm{cells}^{-1}$ in A549. However, IL-8 secretion by SCLC cells was almost negative at $24 \mathrm{~h}$ and detectable in only three of six SCLC cell lines at $48 \mathrm{~h}$ : $162 \mathrm{pg} \mathrm{ml}^{-1} 10^{6} \mathrm{cells}^{-1}$ in $\mathrm{H} 69,109 \mathrm{pg} \mathrm{ml}^{-1} 10^{6}$ cells $^{-1}$ in $\mathrm{H} 345$ and $100 \mathrm{pg} \mathrm{ml}^{-1} 10^{6}$ cells $^{-1}$ in H711 (Figure 1B).

\section{Expression of CXCR1 and CXCR2 in lung cancer cells}

Expression of IL- 8 receptors, CXCR1 and CXCR2, was assessed by flow cytometry and RT - PCR (Figure 2). Expression of CXCR1 and CXCR2 protein on the cell membrane was measured by flow cytometry (Figure 2A and B). In the SCLC cell lines, the number of CXCR1-positive cells in Lu165 was 68\%, followed by CORL24 with $45 \%$ and then the other four cell lines with between 36 and $38 \%$. In NSCLC cell lines, the number of CXCR1-positive cells was $35 \%$ in $\mathrm{H} 460$ and $26 \%$ in MOR/P, and a few positive cells were found in A549. In contrast to CXCR1, expression of CXCR2 was much lower in all cell lines tested, ranging from $28 \%$ in $\mathrm{H} 711$ to $9 \%$ in MOR/P. The NSCLC cell line A549 was negative for CXCR2 protein (Figure 2C). We further compared the mRNA levels of CXCR1 and CXCR2 in A549 and H460. CXCR1 mRNA was present in A549 but at a lower level than in H460. CXCR2 mRNA was not present in A549 but in $\mathrm{H} 460$ as expected (Figure 2D).

\section{A}
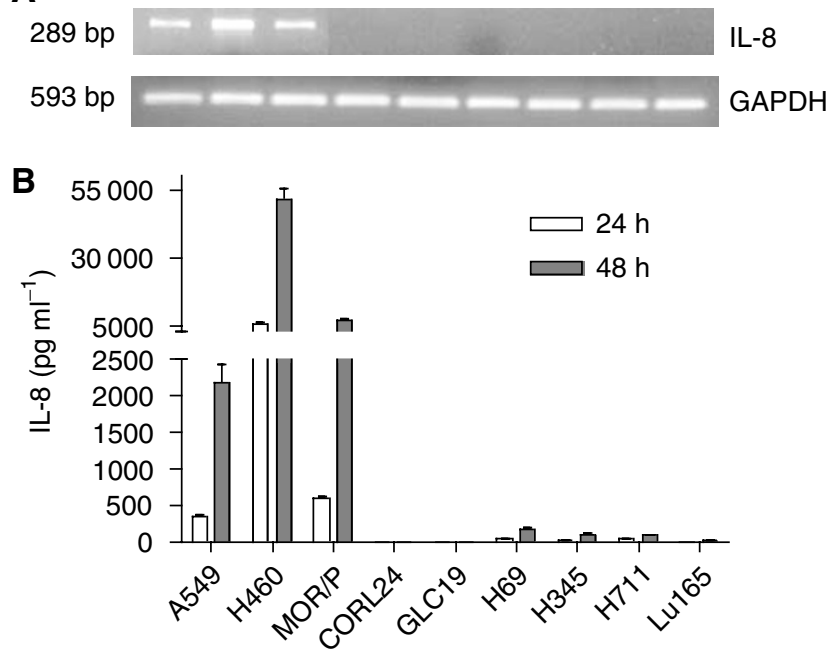

Figure I Expression of IL-8 mRNA and protein in lung cancer cell lines. Expression of IL-8 mRNA was measured by RT-PCR (A). A I $\mu$ g portion of total RNA was reverse-transcribed for PCR reactions of IL-8 and control GAPDH. The expected 289 bp band of IL-8 mRNA was strongly expressed in A549, H460 and MOR/P, but was undetectable in all SCLC cell lines. Production of IL-8 protein was measured by ELISA (B). Conditioned medium was collected after $1 \times 10^{6}$ cells were cultured in serum-free RPM medium for $48 \mathrm{~h}$. Each bar is the mean \pm s.e. of three determinations from two independent experiments.
Interleukin-8 is an autocrine growth factor in $\mathrm{H} 460$ and MOR/P cells

Although all the NSCLC cell lines produced IL-8, only two of them (H460 and MOR/P) expressed IL-8 receptors, as there were almost
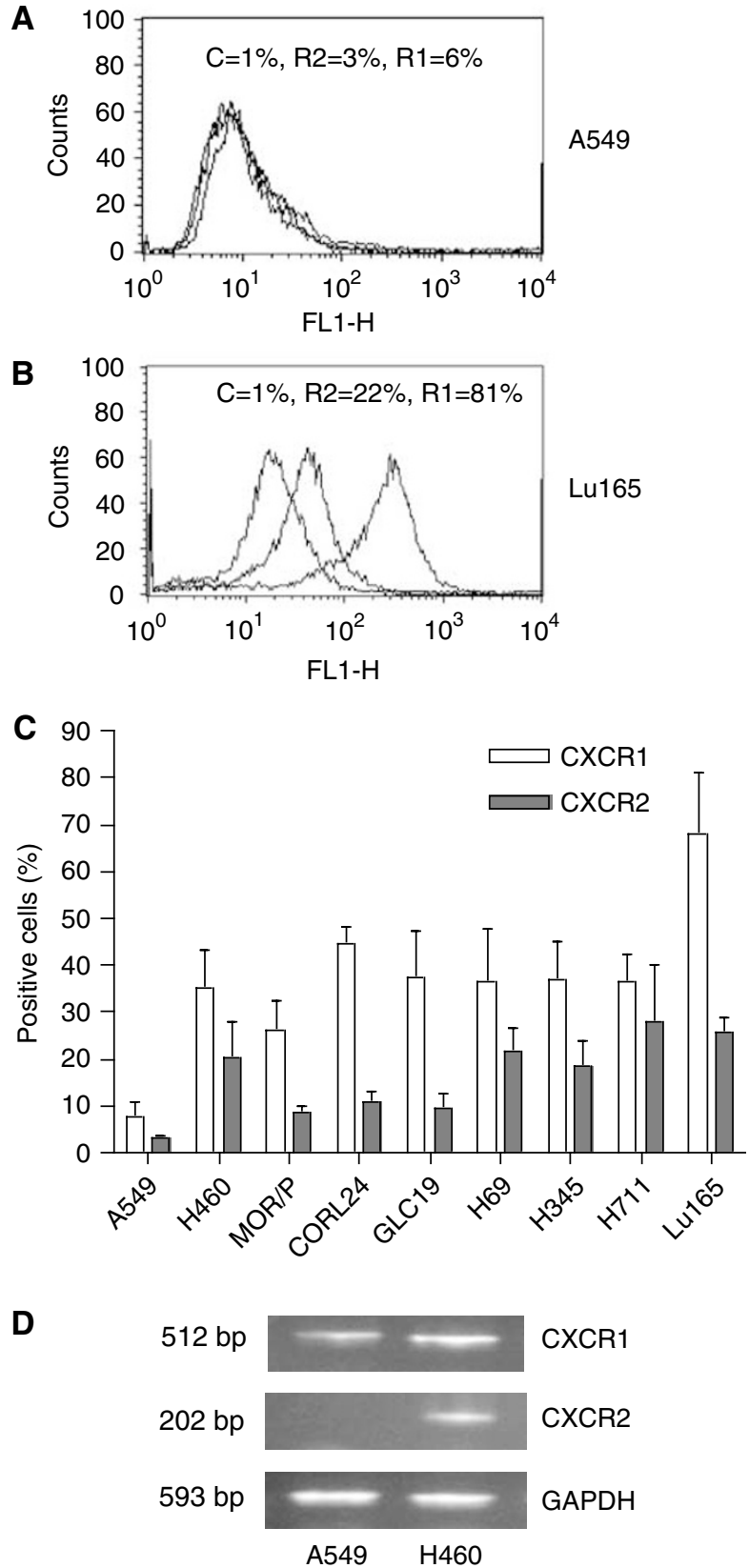

Figure 2 Expression of CXCRI and CXCR2 in lung cancer cell lines Expression of CXCRI and CXCR2 proteins on the cell surface was measured by flow cytometry with mouse anti-human CXCRI (RI) and CXCR2 (R2) and mouse IgG as control (C). Representative flow cytometric histograms of A549 and Lul65 showing the low expressions of CXCRI and CXCR2 in A549 (A) and high expressions of CXCRI and CXCR2 in Lul65 (B), respectively. Percentage of positive cells of CXCR I and CXCR2 in nine lung cancer cell lines are summarised in $(\mathbf{C})$. Each bar is the mean \pm s.e. of four independent experiments. Expression of CXCRI and CXCR2 mRNA was measured by RT-PCR in A549 and H460 (as a positive control) (D). Total RNA (I.5 $\mu \mathrm{g}$ ) was reverse-transcribed for PCR reactions of CXCRI, CXCR2 and control GAPDH. The expected 512 bp band of CXCRI was expressed in A549 and H460. The expected 202 bp band of CXCR2 was expressed in control cell H460 but not in A549 cells. 
no detectable CXCR1 and CXCR2 proteins on the surface of A549. Consistent with this, cell proliferation was enhanced by exogenous rIL-8 in H460 and MOR/P, but not in A549 (Figure 3A). We also tested whether expression of IL-8 receptors was associated with cell proliferation. When NSCLC cells were 50\% confluent, $36 \%$ cells were in $G_{1}$ phase and $64 \%$ cells were in $S$ and $G_{2} / M$ phases. In contrast, $67 \%$ cells were in $\mathrm{G}_{1}$ phase and $33 \%$ cells were in $S$ and $\mathrm{G}_{2} / \mathrm{M}$ phases when cells were $100 \%$ confluent. The number of positive cells with CXCR1 or CXCR2 was significantly higher in $50 \%$ confluent cells than in $100 \%$ confluent cells. Positive cells with CXCR 1 and CXCR2 were increased to 43 and $28 \%$ from 22 and $6 \%$ (both $P<0.01$ ), respectively, in H460. Positive cells with CXCR1 and CXCR2 were increased to 33 and $11 \%$ from 21 and $6 \%$ (both $P<0.01$ ), respectively, in MOR/P (Table 1).

To test whether IL- 8 acted as an autocrine growth factor in these two cell lines, cells were cultured in the presence or absence of anti-IL-8 antibody. Cell growth was inhibited in a dose-dependent fashion by adding anti-IL-8 antibody. At a concentration of $10 \mu \mathrm{g} \mathrm{ml}^{-1}$ of anti-IL8 antibody, cell proliferation was significantly reduced to $71 \%(P<0.05)$ and $76 \%(P<0.05)$ in $\mathrm{H} 460$ and MOR/P, respectively. In contrast, cell proliferation was not significantly changed in A549 (Figure 3B). To determine which IL-8 receptor mediates growth in NSCLC, we examined the effects of anti-CXCR1 and anti-CXCR2 on cell proliferation. Anti-CXCR1 antibody significantly reduced cell proliferation of $\mathrm{H} 460$ (to $75 \%, P<0.05$ ) and MOR/P (to $82 \%, P<0.05$ ) at a concentration of $10 \mu \mathrm{g} \mathrm{ml}^{-1}$, whereas anti-CXCR2 antibody did not significantly affect cell proliferation of these cells (Figure 3C). A549, which lack surface receptors, did not respond to either antibody.

\section{Exogenous rIL-8 stimulates SCLC cell proliferation through mainly CXCR1}

Because SCLC cell lines expressed IL-8 receptors but did not secrete IL-8, it could not act as an autocrine growth factor for these cells. However, exogenous rIL-8 stimulated SCLC cell proliferation in a dose-dependent fashion (Figure 4). Maximal stimulation was obtained in three out of four tested cell lines at a concentration of $1 \mathrm{ng} \mathrm{ml}^{-1}$. Cell growth was increased by $33 \%(P<0.05)$ in GLC-19, $31 \%(P<0.05)$ in $\mathrm{H} 345$ and $18 \%(P<0.05)$ in H69. Cell proliferation of Lu165 was increased to $37 \%(P<0.05)$ with rIL-8 at $10 \mathrm{ng} \mathrm{ml}^{-1}$ (Figure 4A). To support this result, expression of PCNA, a marker for proliferating cells, and cell cycle were analysed in $\mathrm{H} 69$ cells. After IL-8 stimulation $\left(1 \mathrm{ng} \mathrm{ml}^{-1}\right)$, the mean fluorescent intensity (MFI) of PCNA was increased to 65 from 35 in $\mathrm{H} 69$ (Figure $4 \mathrm{~B}$ ); the $\mathrm{G}_{1}$ phase was decreased to $29 \%$ from $43 \%$, and $S$ and $\mathrm{G}_{2} / \mathrm{M}$ phases were increased to 41 and $30 \%$ from 38 and $19 \%$, respectively (Figure 4C). To determine which IL-8 receptor was involved in IL-8 stimulation, cells were treated with either anti-CXCR1 $\left(10 \mu \mathrm{g} \mathrm{ml}^{-1}\right)$ or anti-CXCR2 $\left(10 \mu \mathrm{g} \mathrm{ml}^{-1}\right)$ and rIL-8 for $48 \mathrm{~h}$. Anti-CXCR1 antibody significantly reduced the proliferation stimulated by IL- 8 in all SCLC cell lines $(P<0.05)$. However, antiCXCR2 antibody did not significantly reduce the proliferation (Figure 4D), indicating that the mitogenic effects of IL-8 in SCLC are mainly mediated by the CXCR 1 receptor.

\section{DISCUSSION}

Interleukin-8 has been shown to be an important mitogenic factor in a variety of cancers including melanoma (Schadendorf et al, 1993; Singh et al, 1994), colon cancer (Brew et al, 2000; Li et al, 2001), pancreatic cancer (Miyamoto et al, 1998), malignant mesothelioma (Galffy et al, 1999) and Kaposi's sarcoma (Masood et al, 2001). The role of IL-8 in lung cancer has not been fully defined. Although there are several reports on lung cancer-derived IL-8 and its effect on tumour growth, their results remain controversial and unclear. Wang et al (1996) reported that
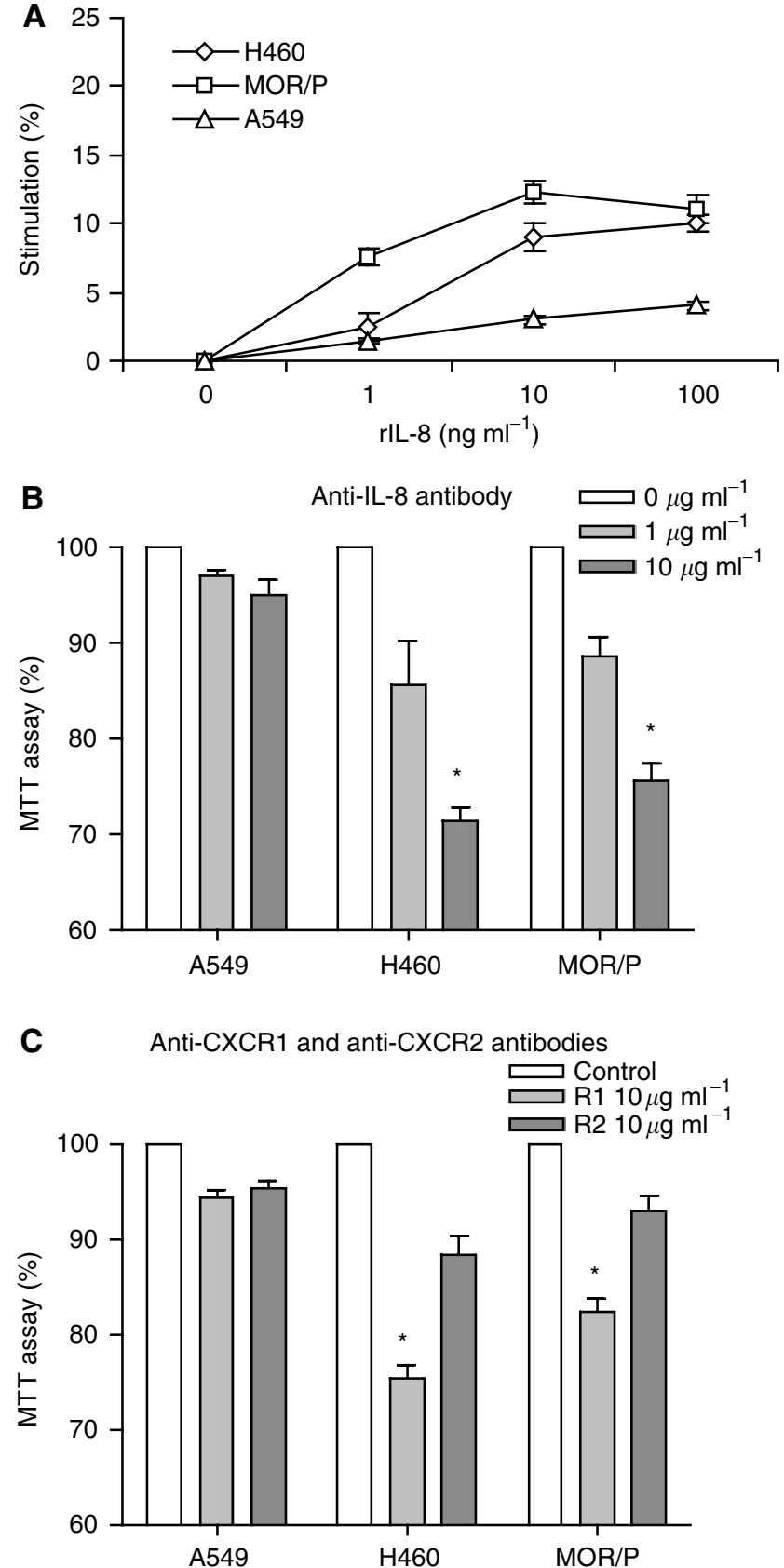

Figure 3 Interleukin-8 is an autocrine growth factor in $\mathrm{H} 460$ and MOR/P cells. (A) Non-small cell lung cancer cells were treated with rlL-8 (at a concentration of $0,1,10$ and $100 \mathrm{ng} \mathrm{ml}^{-1}$ ) for $48 \mathrm{~h}$. Cell proliferation was measured by MTT assay. Each point is the mean \pm s.e. of three determinations from two independent experiments. (B) Non-small cell lung cancer cells were treated with anti-IL-8 neutralising antibody (I or $10 \mu \mathrm{g} \mathrm{ml}^{-1}$ ) for $48 \mathrm{~h}$. Cell proliferation was measured by MTT assay. Each bar is the mean \pm s.e. of three determinations from two independent experiments. $* P<0.05$. (C) Non-small cell lung cancer cells were treated with anti-CXCRI or anti-CXCR2 neutralising antibody $\left(10 \mu \mathrm{g} \mathrm{ml}^{-1}\right)$ or control antibody (mouse lgG at $10 \mu \mathrm{gml}^{-1}$ ) for $48 \mathrm{~h}$. Cell proliferation was measured by MTT assay. Each bar is the mean \pm s.e. of three determinations from two independent experiments. $* P<0.05$.

exogenous rIL-8 and cancer-derived IL-8 inhibited lung tumour proliferation by both autocrine and paracrine pathways in A549 and four other lung cancer cell lines. However, Arenberg et al reported that tumour-derived IL-8 directly correlated with the rate 
Table I Correlation of expression of CXCRI and CXCR2 with cell proliferation

\begin{tabular}{|c|c|c|c|c|}
\hline & \multicolumn{2}{|c|}{ H460 } & \multicolumn{2}{|c|}{ MOR/P } \\
\hline & $100 \%$ confluency & $\mathbf{5 0} \%$ confluency & $100 \%$ confluency & $\mathbf{5 0} \%$ confluency \\
\hline $\begin{array}{l}\text { CXCRI (\%) } \\
\text { CXCR2 (\%) }\end{array}$ & $\begin{array}{r}22.6 \pm 1.7 \\
6.1 \pm 0.5\end{array}$ & $\begin{array}{l}43.5 \pm 3.3^{*} \\
28.2 \pm 2.4^{*}\end{array}$ & $\begin{array}{r}21.0 \pm 1.6 \\
6.2 \pm 0.4\end{array}$ & $\begin{array}{l}33.0 \pm 1.7^{*} \\
11.0 \pm 0.6^{*}\end{array}$ \\
\hline
\end{tabular}

${ }^{*} P<0.01$.

A

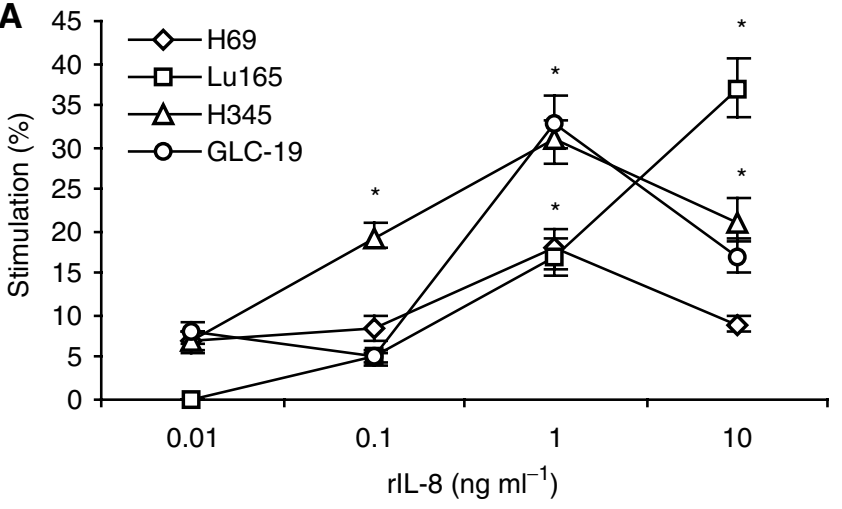

C
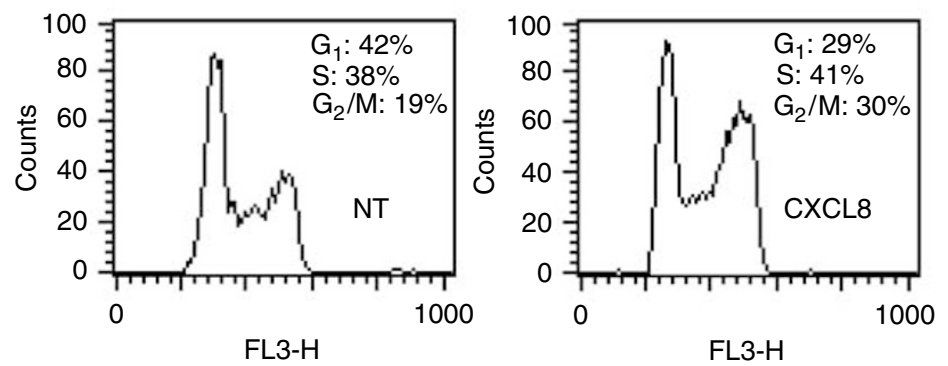

B
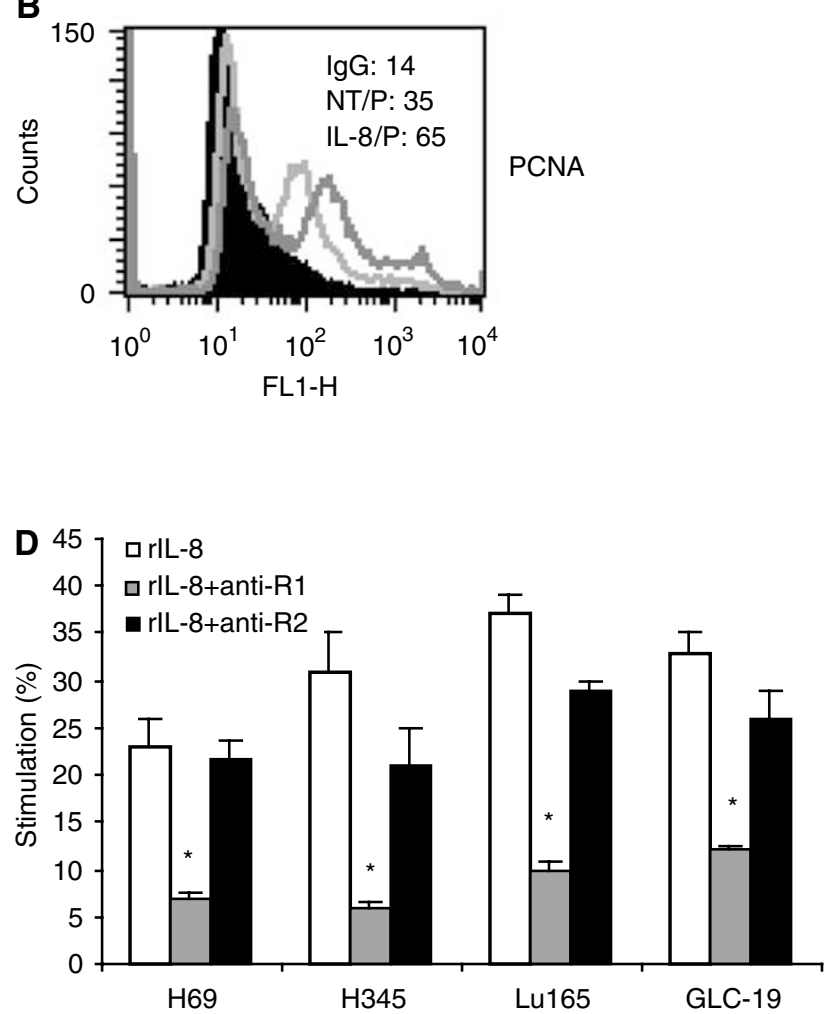

Figure 4 Recombinant IL-8 stimulates SCLC cell proliferation through CXCRI. (A) The SCLC cell lines H69, LuI65, H345 and GLC-I9 were treated with rlL-8 at concentrations of $0.0 \mathrm{I}, 0 . \mathrm{I}, \mathrm{I}$ and $10 \mathrm{ng} \mathrm{ml}{ }^{-1}$ for $48 \mathrm{~h}$. Cell proliferation was measured by MTT assay. Each point is the mean \pm s.e. of three determinations from two independent experiments. ${ }^{*} P<0.05$. (B) Detection of PCNA intensity by flow cytometry after H69 cells was treated with rIL-8 $\left(\mathrm{I} \mathrm{ng} \mathrm{ml} \mathrm{I}^{-1}\right)$ for $48 \mathrm{~h}$. (C) Analysis of DNA content by flow cytometry after $\mathrm{H} 69$ cells was treated with rlL-8 (I ng ml $\left.{ }^{-1}\right)$. (D) Small cell lung cancer cells were treated with rlL-8 plus anti-CXCRI or anti-CXCR2 antibody for $48 \mathrm{~h}$. The concentration of rIL-8 for each cell line was chosen for maximal stimulation: $10 \mathrm{ng} \mathrm{ml}^{-1}$ for Lul 65 and I $\mathrm{ng} \mathrm{ml}^{-1}$ for others. The final concentration of anti-CXCRI or anti-CXCR2 was $10 \mu \mathrm{g} \mathrm{ml}{ }^{-1}$. Each bar is the mean \pm s.e. of three independent determinations of two experiments. $* P<0.05$ for inhibition of rlL-8-induced proliferation by anti-CXCRI antibody.

of growth of the two human NSCLC cells lines A549 and Calu-1 in SCID mice. Interleukin-8 promoted human lung cancer growth through its angiogenic properties. Interleukin-8 was not found to behave as an autocrine growth factor for the proliferation of NSCLC cells (Arenberg et al, 1996). The expression of CXCR1 and CXCR2 was not investigated in these reports. The present study has investigated the expression of both IL-8 and its receptors simultaneously for the first time in a panel of lung cancer cell lines. We found that NSCLC cells produced significant amounts of IL-8. However, SCLC cells produced low or undetectable levels of IL-8. These results were in agreement with previous studies. Many NSCLC cells including A549 and H460 were shown to produce IL-8 (Arenberg et al, 1996; Yatsunami et al, 1997; Anderson et al, 2000; Chen et al, 2003) and SCLC cells including H345 were shown to produce low or undetectable levels of IL-8 (Yatsunami et al, 1997).
Since the expression of CXCR1 and CXCR2 has not been studied in lung cancer cells, we next examined the expression of these receptors on cell surface by flow cytometry. In NSCLC cells, CXCR1 and CXCR2 were found on H460 and MOR/P, but very few CXCR1 and no CXCR2 were found on A549. By RT-PCR, A549 expressed CXCR1 mRNA but not CXCR2 mRNA. In SCLC cells, CXCR1 and CXCR2 were expressed in all cell lines. SCLC cells responded to exogenous rIL-8 in a dose-dependent fashion. Cell proliferation reached a peak at an rIL-8 concentration of $1 \mathrm{ng} \mathrm{ml}^{-1}$ in most cell lines, but cell proliferation reached a peak at an rIL-8 concentration of $10 \mathrm{ng} \mathrm{ml}^{-1}$ in Lu165. This may reflect the fact that Lu165 cell expressed more receptors, especially CXCR1, than other cells. These results indicated that IL- 8 could act as a paracrine growth factor in SCLC cells.

The finding that IL-8 and its receptors are coexpressed in H460 and MOR/P cell lines led us to speculate that IL-8 could act as an 
autocrine growth factor in these cells. We demonstrated that cell growth was stimulated by exogenous rIL-8 in H460 and MOR/P, but not in A549. Also, cell growth was significantly inhibited in a dose-dependent fashion by adding anti-IL-8 neutralising antibody to 71 and $76 \%$ in $\mathrm{H} 460$ and MOR/P, respectively. In contrast, cell proliferation was only slightly decreased in A549. These results suggest that IL-8 is an autocrine growth factor in H460 and MOR/ P, but not in A549 NSCLC cells because they lack receptors. This may explain why IL-8 was not found to act as an autocrine growth factor in A549 cells in a previous study (Arenberg et al, 1996).

We further investigated which IL-8 receptor(s) mediated the mitogenic function of IL-8 in lung cancer cells. The biological activity of IL- 8 is mediated by binding to two closely related receptors, CXCR1 and CXCR2. CXCR1 binds only IL-8 and CXCL6 (granulocyte chemotactic protein-2, GCP-2), but CXCR2 binds all known angiogenic CXC chemokines that contain the Glu-Leu-Arg (ELR) motif including IL-8 (Lee et al, 1992). Our results showed that all the lung cancer cell lines tested expressed CXCR 1 and CXCR2 except A549. In these cell lines, expression of CXCR2 protein was much weaker than CXCR1. The role of each of these receptors in IL-8-mediated activity remains controversial. Previous studies have shown that the angiogenic effects of IL-8 in human microvascular endothelial cells and NSCLC were mediated by CXCR2 (Addison et al, 2000; Salcedo et al, 2000; Heidemann et al,
2003). The chemotactic response of melanoma cells to IL-8 was mediated by CXCR1 (Ramjeesingh et al, 2003), and the mitogenic activity of IL- 8 was mediated by both CXCR1 and CXCR2 in colon cancer (Li et al, 2001), but only by CXCR1 in monocytes (Browning et al, 2000). Our results show that CXCR1 is the major receptor that mediates the mitogenic function of IL- 8 in lung cancer. Also, there was evidence of crosstalk between the IL-8 and epidermal growth factor (EGF) receptors. Venkatakrishnan et al (2000) reported that in ovarian cancer cells the signal through CXCR1 and CXCR2 by IL- 8 transactivated EGF receptor, which is an effective therapeutic target of many EGF receptor inhibitors in NSCLC. Overall, we have shown that IL-8 can function as an autocrine and/or paracrine growth factor in lung cancer cells. Therefore, targeting both IL-8 production and CXCR1 expression may contribute to control of lung cancer progression, invasion and metastasis through both angiogenic and mitogenic properties of IL-8.

\section{ACKNOWLEDGEMENTS}

This work was supported by Yorkshire Cancer Research and Weston Park Hospital Cancer Appeal.

\section{REFERENCES}

Addison CL, Daniel TO, Burdick MD, Liu H, Ehlert JE, Xue YY, Buechi L, Walz A, Richmond A, Strieter RM (2000) The CXC chemokine receptor 2, CXCR2, is the putative receptor for ELR+ CXC chemokine-induced angiogenic activity. J Immunol 165: 5269-5277

Anderson IC, Mari SE, Broderick RJ, Mari BP, Shipp MA (2000) The angiogenic factor interleukin 8 is induced in non-small cell lung cancer/ pulmonary fibroblast cocultures. Cancer Res 60: 269-272

Arenberg DA, Kunkel SL, Polverini PJ, Glass M, Burdick MD, Strieter RM (1996) Inhibition of interleukin-8 reduces tumorigenesis of human non-small cell lung cancer in SCID mice. J Clin Invest 97: $2792-2802$

Baggiolini M, Walz A, Jundel SL (1989) Neutrophil-activating peptide-1/ interleukin-8, a novel cytokine that activates neutrophils. J Clin Invest 84: $1045-1052$

Brew R, Erikson JS, West DC, Kinsella AR, Slavin J, Christmas SE (2000) Interleukin-8 as an autocrine growth factor for human colon carcinoma cells in vitro. Cytokine 12: 78-85

Browning DD, Diehl WC, Hsu MH, Schraufstatter IU, Ye RD (2000) Autocrine regulation of interleukin-8 production in human monocytes. Am J Physiol Lung Cell Mol Physiol 279: L1129-L1136

Chen JJW, Yao PL, Yuan A, Hong T-M, Shun C-T, Kuo M-L, Lee Y-C, Yang P-C (2003) Up-regulation of tumor interleukin-8 expression by infiltrating macrophages: its correlation with tumor angiogenesis and patient survival in non-small cell lung cancer. Clin Cancer Res 9: $729-737$

Galffy G, Mohammed KA, Dowling PA, Nasreen N, Ward MJ, Antony VB (1999) Interleukin 8: an autocrine growth factor for malignant mesothelioma. Cancer Res 59: $367-371$

Heidemann J, Ogawa H, Dwinell MB, Rafiee P, Maaser C, Gockel HR, Otterson MF, Ota DM, Lugering N, Domschke W, Binion DG (2003) Angiogenic effects of interleukin 8 (CXCL8) in human intestinal microvascular endothelial cells are mediated by CXCR2. $J$ Biol Chem 278: $8508-8515$

Lee J, Horuk R, Rice GC, Bennett GL, Camerato T, Wood WI (1992) Characterization of two high affinity human interleukin-8 receptors. $J$ Biol Chem 267: 16283-16287

Li A, Varney ML, Singh RK (2001) Expression of interleukin-8 and its receptors in human colon carcinoma cells with different metastatic potentials. Clin Cancer Res 7: 3298-3304

Luca M, Huang S, Gershenwald JE, Singh RK, Reich R, Bareli M (1997) Expression of interleukin-8 by human melanoma cells up-regulates MMP-2 activity and increases tumor growth and metastasis. Am J Pathol 151: $1105-1113$

Masood R, Cai J, Tulpule A, Zheng T, Hamilton A, Sharma S, Espina BM, Smith DL, Gill PS (2001) Interleukin-8 is an autocrine growth factor and a surrogate marker for Kaposi's sarcoma. Clin Cancer Res 7: 2693-2702

Masuya D, Huang C, Liu D, Kameyama K, Hayashi E, Yamauchi A, Kobayashi S, Haba R, Yokomise H (2001) The intratumoral expression of vascular endothelial growth factor and interleukin-8 associated with angiogenesis in nonsmall cell lung carcinoma patients. Cancer 92: $2628-2638$

Miyamoto M, Shimizu Y, Okada K, Kashii Y, Higuchi K, Watanabe A (1998) Effect of interleukin-8 on production of tumor-associated substances and autocrine growth of human liver and pancreatic cancer cells. Cancer Immunol Immunother 47: 47-57

Orditura M, De Vita F, Catalano G, Infusino S, Lieto E, Martinelli E, Morgillo F, Castellano P, Pignatelli C, Galizia G (2002) Elevated serum levels of interleukin- 8 in advanced non-small cell lung cancer patients: relationship with prognosis. I Interferon Cytokine Res 22: 1129-1135

Ramjeesingh R, Leung R, Siu CH (2003) Interleukin-8 secreted by endothelial cells induces chemotaxis of melanoma cells through the chemokine receptor CXCR1. FASEB J 17: 1292-1294

Salcedo R, Resau JH, Halverson D, Hudson EA, Dambach M, Powell D, Wasserman K, Oppenheim JJ (2000) Differential expression and responsiveness of chemokine receptors (CXCR1-3) by human microvascular endothelial cells and umbilical vein endothelial cells. FASEB J 14: 2055 - 2064

Schadendorf D, Moller A, Algermissen B, Worm M, Sticherling M, Czarnetzki BM (1993) IL-8 produced by human malignant melanoma cells in vitro is an essential autocrine growth factor. J Immunol 151: $2667-2675$

Singh RK, Gutman M, Radinsky R, Bucana CD, Fidler IJ (1994) Expression of interleukin-8 correlates with the metastatic potential of human melanoma cells in nude mice. Cancer Res 54: 3242-3247

Smith DR, Polverini PJ, Kunkel SJ, Orringer MB, Whyte RI, Burdick MD, Wike CA, Strieter RM (1994) Inhibition of IL-8 attenuates angiogenesis in bronchogenic carcinoma. J Exp Med 179: 1409-1415

Ueda T, Shimada E, Urikawa T (1994) Serum levels of cytokines in patients with colorectal cancer: possible involvement of interleukin-6 and interleukin-8 in hematogenous metastasis. J Gastroenterol 29: 423-429

Venkatakrishnan G, Salgia R, Groopman JE. (2000) Chemokine receptors CXCR-1/2 activate mitogen-activated protein kinase via the epidermal growth factor receptor in ovarian cancer cells. J Biol Chem 275: $6868-6875$

Wang J, Huang M, Lee P, Komanduri K, Sharma S, Chen G, Dubinett SM (1996) Interleukin-8 inhibits non-small cell lung cancer proliferation: a 
possible role for regulation of tumor growth by autocrine and paracrine pathways. J Interferon Cytokine Res 16: 53-60

Wess J (1997) G-protein-coupled receptors: molecular mechanisms involved in receptor activation and selectivity of G-protein recognition. FASEB J 11: $346-354$

Woll PJ (1996) Growth-factors and lung cancer. In Lung Cancer: Principles and Practice Pass HI, Mitchell JB, Johnson DH, Turrisi AT (eds) pp 123 131. Philadelphia: Lippincott-Raven
Yatsunami J, Tsuruta N, Ogata K, Wakamatsu K, Takayama K, Kawasaki M, Nakanishi Y, Hara N, Hayashi S (1997) Interleukin-8 participates in angiogenesis in non-small cell, but not small cell carcinoma of the lung. Cancer Lett 120: $101-108$

Yuan A, Yang PC, Yu CJ, Chen WJ, Lin FY, Kuo SH, Luh KT (2000) Interleukin-8 messenger ribonucleic acid expression correlates with tumor progression, tumor angiogenesis, patient survival, and timing of relapse in non-small-cell lung cancer. Am J Respir Crit Care Med 162: 1957-1963 